\title{
IMPROVING ACTIVE LEARNING THROUGH STUDENTS' POWERPOINT PRESENTATIONS ON REPORT TEXT SPEAKING SKILL
}

\author{
Ahmila Novita \\ SMP N 1 Bandungan \\ ahmilanovita@gmail.com
}

\begin{abstract}
This study was carried out to improve active learning through students' PowerPoint presentations on report text speaking skill in the third grade students of class 9A of SMP N 1 Bandungan 2014/2015 academic year. The method used in this study was Classroom Action Research (CAR) which consists of planning, acting, observing, and reflecting. The study was carried out in two cycles. Each cycle consisted of one meeting 200 minutes (block schedule). The data of this study was gathered through: (1) Student' presentations, (2) observations, and (3) students consultation. The result of the study showed that there was improvement of active learning in the teaching and learning process of class 9A; 100\% was active in group work, $100 \%$ was active in consulting their difficulties with the teacher, $79.2 \%$ was active in finding resources of report text material, $87.5 \%$ was active in asking questions and $90 \%$ was active in answering questions. From the last two indicators can be seen that there is improvement of the active learning of students'speaking skill in asking and answering questions. In conclusion active learning through students' PowerPoint presentations could increase the active teaching and learning process of class $9 \mathrm{~A}$, especially on their report text speaking skill.
\end{abstract}

Key words: active learning, student PowerPoint presentations, report text, speaking skill 


\section{Introduction}

The 2006 Curriculum states the objectives of English instruction in junior and senior high schools are as follows (translated from Indonesian in Depdiknas, 2006) are (1) Developing communicative competence in spoken and written English which comprises listening, speaking, reading, and writing, (2) Raising awareness regarding the nature and importance of English as a foreign language and as a major means for learning, and (3) Developing understanding of the interrelation of language and culture as well as cross-cultural understanding.

When I taught class 9A about Report text in semester 1, I found some problems. When I explained a topic about report text, they sat and listened quietly. No one spoke. I thought that it was a good condition; they listened and paid attention to the lesson carefully. However, when I asked them whether they understood the lesson or not, most of them also just kept silent. Only 3 to 5 students answered. When I gave them a task, they started to whisper each other. It seemed that some students did not really understand what I explained. Although some of them could do the task well, they did not want to present their results in front of class.

I realize learning report text is a little bit difficult and more complicated than the previous four texts that the students have learned before; descriptive, recount, narrative and procedure. Report text needs much knowledge and uses many scientific words. Many of the words are new for them. They have to spend their time more to look for the words in dictionaries, unless they can guess the meaning of the words or they have already known about the topic. Considering these conditions, I tried to teach this topic by using students' PowerPoint presentations.

Why did I choose presentation to improve active learning in my class? Chivers stated that presentations offer variety and challenges that contrast with regular delivery by an academic lecturer. Students can sometimes be more willing to learn from the poor and good performances of their peers than from their tutors. Presentations can also be used as an effective form of peer learning. By taking responsibility for preparing and delivering a presentation, students 
take an active role in the process of their learning. Presentations offer opportunities for developing skills and knowledge together. This process can strengthen learning and enthusiasm for further knowledge. Students' presentations usually involve an individual or group of students presenting to academic staff, student peers or other invited audiences. In this research, I focused on the purpose of teaching and learning presentation. Chivers (2007) said that the content of this presentation is usually focused on a topic area relevant to a course or module being studied. This may involve new research and knowledge that extends how the topic has previously been taught by the teachers. It may also involve 'repackaging' knowledge already covered or further exploration of the topic by looking at different perspectives. Sometimes, these types of students' presentations are used to explore areas of a curriculum in greater detail than has been covered in lectures. This helps the presenters to develop deeper knowledge and the audience to broaden their understanding of the topic

\section{Background Literature}

Different teaching and learning methods relating to active learning have been the subjects of many research studies. The purpose is to find which types are the most beneficial for students. Mayers and Jones (1993) stated that Active learning involves providing opportunities for students to meaningfully talk and listen, write, read, and reflect on the content, ideas, issues, and concerns of an academic subject.

Furthermore, Bonwell noted that there are some major characteristics associated with active learning strategies, they include;(1) Students are involved in more than passive listening.(2) Students are engaged in activities (e.g., reading, discussing, writing).(3) There is less emphasis placed on information transmission and greater emphasis placed on developing student skills. (4). There is greater emphasis placed on the exploration of attitudes and values.(5). Students' motivation is increased (especially for adult learners). (6) Students can receive immediate feedback from their instructor. (7) Students are involved in higher order thinking (analysis, synthesis, 
evaluation). Bonwell and Edison also said that active learning instructional strategies can be (1) completed by students either inclass or out-of-class, (2) done by students working either as individuals or in group, and (3) done either with or without the use of technology tools . In this study I have conducted five limitations of students being active in the teaching and learning process. Those were students were active in a groupwork, in finding resources of their presentations, in consulting their presentations, active in asking and answering questions

For the students' presentation media, I chose to use multimedia PowerPoint presentation, Mayer (2009) asserted that multimedia presentation offers many possibilities to facilitate knowledge construction. Likewise, Verhoeven and Perfetti (2008) suggested that researchers had to examine how students learn from multimedia text, especially now that ICT is progressively being integrated into the school curriculum.

ICT is progressively being integrated into school curriculum. Teachers and students have opportunities in exploring all the information they need easily, of course, teachers must guide the students to do this. According to the National Council for Accreditation of Teacher Education (NCATE, 1997), the current issues are not about using technology in education or ignoring it, but it is about how to employ this technology in the teaching and learning process in a proper way (NCATE), 1997). The fact that the use of technology has become a reality cannot be ignored (Guemide \& Benachaiba, 2012).

According to Bashir, Marriam,et.al (2011) speaking is productive skill in the oral mode. It is like the other skills, is more complicated than it seems at first and involves more than just pronouncing words. Interactive speaking situations include face-to-face conversations and telephone calls, in which we are alternately listening and speaking, and in which we have a chance to ask for clarification, repetition, or slower speech from our conversation partner. Some speaking situations are partially interactive, such as when giving a speech to a live audience, where the convention is that the audience does not interrupt the speech. The speaker nevertheless can 
see the audience and judge from the expressions on their faces and body language whether or not he or she is being understood. Some few speaking situations may be totally non-interactive, such as when recording a speech for a radio broadcast. They added that speaking involves three areas of knowledge: (1) Mechanics (pronunciation, fluency, grammar and diction): Using the right words in the right order with the correct pronunciation. (2) Functions (transaction and interaction): Knowing when clarity of message is essential (transaction/information exchange) and when precise understanding is not required (interaction/relationship building) (3) Social and cultural rules and norms (turn-taking, rate of speech, length of pauses between speakers, relative roles of participants): Understanding how to take into account who is speaking to whom, in what circumstances, about what, and for what reason.

Report text is a text which presents information about something, as it is and as a result of systematic observation and analysis. There are some social functions of report text stated by some experts. According to Hardy and Klarweim (1990) report was to inform, Derewianka (1990) said that report text was to document, organize and store factual information on a topic ... classify and describe the phenomena of our world ... about a whole class of things ... [not about] one specific thing ... about living things like plants and animals, and non-living things like phones, bikes, or oceans, and Gerot danWignell (1994) said that report text was to describe the way things are, with reference to a range of natural, man-made and social phenomena in our environment.

\section{Methods}

The study was designed to seek the answer of the question "how can active learning through student PowerPoint presentations can improve the active teaching and learning process on report text speaking skill of class 9A?"The Variables of the Study were Independent variable; the learning process by using student PowerPoint presentations and Dependent variable; the improvement of active learning on Report text.The Instruments of the study were observation, student 'PowerPoint presentations and students' consulta- 
tion'The technique of data analysis used in this study was descriptive percentage analysis. In the analysis, I described the percentage improvement of active learning through students' presentations on Report text. The data got from observation are analyzed by making a table of the data from observation sheet and analyzing the data using descriptive percentage (DP).

\section{Finding}

\section{Findings of the First Cycle}

Unwanted I arranged three activities in this cycle; the pre-presentation, presentation and post presentation activities. For pre-presentation activities, there were three sessions that I and the observers observed in this stage. They were how students were active in the group work, how they were active in consulting their topic and the last was how they were active in finding resources.

I made certain conditions to make every member of the group active in their group work. To avoid the free-rider I always asked all the members of the group came to me if the group wanted to have consultation. Then I asked the group to present their presentation take in turns. Every member must have a chance to do presentation. By doing this I and the observers made the students involved actively in the group work. From table 1. It can be seen that all the groups were being active in the group work got score 4, and they were active in consulting their topic got score 3. They all came to me to have consultation. They helped each other in the group performance.

To maximize the activities of having consultation, I always said that a group must consulate their chosen topic before they made PowerPoint presentation. It was done to avoid failures. In this activity, I found that two groups have chosen the wrong titles. I asked them to choose topics of report text, but they chose topics of descriptive text. The topics were Rafflesia Arnoldi and Eiffel Tower. From this situation I realized that the two groups were still confused in making difference between descriptive text and report text. After receiving teacher's explanation finally the groups have understood the difference between descriptive and report text. They tried to 
find new topics and finally they came to me with correct ones. They chose Guava and Dolphin. I also found that all of the groups came to me to have consultation in checking their grammar, spelling and what to say in the beginning of their presentation. For grammar and spelling I told them to use the menu of their notebooks in checking grammar and spelling and for opening their presentation I gave them simple notes how to start their presentation. The next finding in this session was that all groups came to consult their questions and answers. Some groups had made a set of questions and answers and others had not finished yet. These groups said that they had difficulties in arranging their questions.

Report text is like scientific text. We cannot make or arrange this text without any resources or knowledge related to the text. This condition forced students to find resources before they started to write this text. The observers and I found that all of the groups found the resources from the internet. I realized this because it was easier to find information from the internet than from other resources. Moreover, our library is lack of book collections. Table 1 shows that the group got score 1, if they had 1 resource and got score 2 if they had 2 resources. There were four groups which had one resource, and four groups had two resources. I suggested to all groups to find resources in English. However there was one group which got Indonesian resource. That was the bicycle group. This condition made the group difficult to translate in English. When they translated by using Google Translate, the result was not good. Finally they translated the text by using their own dictionaries with the help of the teacher.

The first presentation activities were done on $20^{\text {th }}$ September 2014. Two groups had the first chance to present their topic. They were Ginger group and Train group.There were four sessions in these activities, they were presentation time, difficult words time, free questions time, and answer my questions time.

Ginger group got the first chance to present their topic. In the "presentation time" (first session) this group had interesting presentations by adding animation and the group's photos. Every member presented one paragraph. There were some unsuitable pro- 
nunciation; some audiences gave direct feedback when they made wrong pronunciations. Sometimes they also asked the teacher how to pronounce certain words. They made an interesting PowerPoint presentation by adding some pictures on their presentation. I considered their presentation ran well.

In the "difficult words time" (second session) many audiences (more than half number of the class) asked the meaning of the difficult words. It seemed that those words were new for them. Moreover the audiences did not want to get many problems in doing the task from the presenter in the fourth session. They anticipated this by asking many difficult words. The presenter could answer the words, but they needed 1 to 3 minutes to find the meaning of one word in their notes. It seemed that they were little bit forget about the words.

In the "free questions time" (third session), there were about 5 students raised their hands to ask free questions related to the topic. The other students just waited and saw each other. Although I had told them to prepare the questions at home, there were only five students raised their hands in this session. I was curious to know. What happened with this class? After I asked them why they did not ask questions, they said that they had prepared the questions at home but they were afraid to ask their questions because they felt that their questions not in a good order. Some said that they were afraid if their questions were not qualified ones. Finally this group just got five questions from the audiences. From the five questions, this group could answer 4 questions. In the "answer my question time" (fourth session) the audiences answered 10 questions from the presenters. This session was done in a group.

The last activity was post activity or"Peer evaluation time." In this session the presenters had to give scores for the audiences 'work (session 4). It was done out of school helped by the teacher. The result of this session showed that the audiences did not get difficulties in answering the Ginger questions. There were some groups that made wrong grammatical sentences, and spelling. These finding will be discussed in the next meeting.

The Train group got the second chance to present their topic. 
In the first session this group also had an interesting presentation by adding animations and photos. The members of the group presented the topic one by one. It seemed that they had divided the group task well. There were some unsuitable pronunciation, some audiences gave direct feedback. Like the first group, they also asked the teacher how to pronounce certain words. They also had an interesting PowerPoint presentation by adding some pictures related to the topic. This group seemed tried to learn how to connect the projector to their laptop by themselves. They asked me to guide them. They felt very enthusiastic to use this equipment. They said it was cool to do that. I saw that they enjoyed this learning. Overall I considered their presentation ran well too.

In the "difficult words time", the situation was almost the same with the first group presentation. Many audiences (more than half number of the class) asked the meaning of the difficult words. The presenter could answer the words little bit faster than the previous group. It seemed that they prepared this session well. All of the members had copies of the presentation material including the meaning of it.

In the "free questions time", there were only five students asking free questions, but after I told them not to think their questions were good or no, or qualified or no, finally there were about 13 students raised their hands to ask free questions related to the topic. This group had to choose 10 questions. From the ten questions this group can only answered 6 questions. The fourth session was "answer my question time". In this session the audiences answered 10 questions from the presenters.

The post-presentation activity was "peer evaluation time". In this session the presenters had to give scores for the audiences' work (session 3). It was done out of school helped by the teacher. Like the previous presentations, the result of this session showed that the audiences did not get difficulties in answering the Ginger questions. There were some groups that made wrong grammatical sentences, and spelling. 


\section{Tabel 1. Students' Activities in the Fisrt Cycle}

\begin{tabular}{|c|c|c|c|c|c|c|}
\hline \multirow[b]{2}{*}{ No } & \multirow{2}{*}{$\begin{array}{c}\text { Name } \\
\text { of } \\
\text { Group }\end{array}$} & \multicolumn{5}{|c|}{ Score For Being Active in Learning } \\
\hline & & $\begin{array}{l}\text { Active in } \\
\text { group }\end{array}$ & $\begin{array}{c}\text { Con- } \\
\text { sultasion }\end{array}$ & $\begin{array}{l}\text { Finding } \\
\text { resourch }\end{array}$ & $\begin{array}{l}\text { Asking } \\
\text { question }\end{array}$ & $\begin{array}{c}\text { Answering } \\
\text { question }\end{array}$ \\
\hline 1 & Ginger & 4 & 3 & 1 & 1 & 4 \\
\hline 2 & Train & 4 & 3 & 2 & 5 & 6 \\
\hline 3 & Guava & 4 & 3 & 1 & - & - \\
\hline 4 & Panda & 4 & 3 & 2 & - & - \\
\hline 5 & Bicycle & 4 & 3 & 1 & - & - \\
\hline 6 & Fennel & 4 & 3 & 2 & - & - \\
\hline 7 & Dolphin & 4 & 3 & 2 & - & - \\
\hline 8 & Bird & 4 & 3 & 1 & - & - \\
\hline
\end{tabular}

\section{Findings of the Second Cycle}

Like the previous cycle, in this stage I made certain conditions to make every member of the group active in their group work. To avoid the free-rider I always asked all the members of the group came to me if the group wanted to have consultation. Then I asked the group to present their presentation take in turns. Every member must have a chance to do presentation. By doing this the observer and I made the students involved actively in the group work. They all came to me to have consultation. They helped each other in the group performance. Groups which had not presented their topic yet came to me to consult their works. It seemed that they did not want to repeat the mistakes of the previous groups. They saw me their resources and their PowerPoint presentations. They rearrange their set of questions and asked the meaning of some words. It seemed that every group compete each other, they wanted to be better than other groups. A certain group would be angry if their idea was stolen by others; for example in making animations. Because this was the second cycle of consultation, there were no groups which made wrong text. All of the groups have learned about the difference between descriptive text and report text.

In this second cycle groups added their resources of their topics. They argued that they did not want to do the same mistake like the previous groups and they also avoid having homework if they could not answer their audiences' question.

Two groups presented their topic in this second cycle were 
Guava group and Panda group. In the first session, Guava group made an interesting PowerPoint presentation and added the group's photos and some animations on their presentations. There were some unsuitable pronunciation; some audiences gave direct feedback when they made wrong pronunciations. Sometimes they also asked the teacher how to pronounce certain words. I considered their presentation ran well.

In the "difficult words time" (second session), this group was ready to answer the difficult words from the audiences. Every member had the hard copies of their presentations. They also had made notes of the difficult words to anticipate their audiences' questions. Many audiences (more than half number of the class) asked the meaning of the difficult words. The presenter did not need long time to answer the questions.

In the "free questions time" (third session), there were about 20 students raised their hands to ask free questions related to the topic. Most of them had prepared the questions at home. Even some of them had asked me the grammar of the questions the day before the meeting. Because there were more than 10 questions the presenter had to choose 10 questions. From ten questions, there were only one question that could not be answered, and it would be homework of the group and there were 6 questions that should be corrected grammatically. The presenter, the audiences and the teacher did this activity together. The fourth session was "answer my question time".

In this session the audiences answer 10 questions from the presenters, this session was done individually.

In the post presentation activity or "peer evaluation time" like the first cycle the presenters had to give scores for the audiences 'work. It was done out of school helped by the teacher. The result of this session showed that the audiences did not get difficulties in answering the Ginger questions. There were some groups that made wrong grammatical sentences, and spelling. These findings would be discussed in the next meeting.

Panda group got the fourth chance to present their topic. For the "Presentation Time" (first session) like the previous present- 
ers, there were some unsuitable pronunciation, some audiences gave direct feedback, and they also asked the teacher how to pronounce certain words. They also had an interesting PowerPoint presentation by adding some pictures and their own photos. This group was better in preparation than the former group. They were vey confidence. Overall I considered their presentation ran well too.

In the "difficult words time" (second Session) this group had a good preparation. They used two notebooks on their presentations; one for presenting their topic and the other was used to find other information related to the topic. They also brought hard copies of their resources; all of the members had copies of the presentation material including the meaning of it. They could answer the meaning of the difficult words easily. They helped each other very well in this session. In the "free questions time" (third Session), most of the audiences raised their hands wanted to ask questions. It was about 20 students the presenters were difficult to choose which audience should get the chance to ask questions. This situation made the class really interesting. Audiences raised their hands with standing and screaming; calling the names of the presenter because they wanted to be chosen by the presenters. Finally ten questions were chosen. From those questions this group could answer nine questions. The fourth session was "answer my question time". In this session the audiences answer 10 questions from the presenters; this session was done individually.

The last activity was post activity or "Peer evaluation time." In this session the presenters had to give scores for the audiences' work. It was done out of school helped by the teacher.

Tabel 2. Students' Activities in the Second Cycle

\begin{tabular}{ccccccc}
\hline No & Name Of & Active in & \multicolumn{5}{c}{ Score For Being Active In Learning } \\
& Group & Con- & Finding & Asking & Answering \\
group & sultasion & resourch & question & question \\
\hline 1 & Ginger & 4 & 3 & 2 & 2 & 4 \\
2 & Train & 4 & 3 & 1 & 5 & 9 \\
3 & Guava & 4 & 3 & 3 & 7 & 9 \\
4 & Panda & 4 & 3 & 4 & 7 & 9 \\
5 & Bicycle & 4 & 3 & 3 & - & - \\
6 & Fennel & 4 & 3 & 4 & - & - \\
7 & Dolphin & 4 & 3 & 3 & - & - \\
8 & Bird & 4 & 3 & 2 & - & - \\
\hline
\end{tabular}


The recapitulation data of the preliminary study, the first and the second cycle can be seen in the table 3 .

\section{Table 3.The Recapitulation Data of The Preliminary Study, The First and The SecondCycle}

\begin{tabular}{llccc}
\hline No & \multicolumn{1}{c}{ Students' activities } & $\begin{array}{c}\text { The prelimi- } \\
\text { nary study }\end{array}$ & $\begin{array}{c}1^{\text {st }} \\
\text { Cycle }\end{array}$ & $\begin{array}{c}2^{\text {nd }} \\
\text { Cycle }\end{array}$ \\
\hline 1 & $\begin{array}{l}\text { Students are active in their group } \\
\text { work. }\end{array}$ & $100 \%$ & $100 \%$ \\
\hline $\begin{array}{l}\text { Students are active in finding re- } \\
\text { sources of their presentation. }\end{array}$ & - & $37 \%$ & $79 \%$ \\
3 & $\begin{array}{l}\text { Students are active in consulting their } \\
\text { difficulties }\end{array}$ & - & $100 \%$ & $100 \%$ \\
\hline $\begin{array}{l}\text { Students are active in asking ques- } \\
\text { tions. } \\
\text { Students are active in answering ques- } \\
\text { tions. }\end{array}$ & $25 \%$ & $32 \%$ & $87 \%$ \\
\hline
\end{tabular}

\section{Discussion}

The students' PowerPoint presentations in this first cycle could be said interesting. They added their own photos and added funny animations in their presentation. This made audiences laughed when they saw their friends' photos. They said that they wanted to do the same thing, adding their photos in their presentations. I was very happy and surprised to know how my students' enthusiasm in making their PowerPoint presentations and how they learned much using ICT in this learning. Students were proud to use laptops and projector in the learning process. When I prepared the equipments for them they paid attention carefully and sometimes asked me about the use of the equipment. It seemed that the audiences learned carefully when their friends (presenters) presented their topic. They learned the poorness and the goodness of the previous presenters. The activities of students in asking and answering questions in this cycle was still low because students were afraid to ask questions, they felt unconfident with their English and their questions, they were afraid if it will made other students laugh. But they almost had no problems in answering the presenters' set of 
questions because they had asked the meaning of the difficult words before. In this cycle, Presenters needed a little bit long time to find the meaning of the difficult words because every member of the group did not bring the hard copies of their material. They just brought one or two copies for four presenters. Moreover not all the members of the group read the material the night before their presentation so that some of them forgot about the words. They also could only answer a few of free questions from the audiences because they did not bring their resources of their material, and they also just had one or two resources. Sometimes there were some debates between the presenters and the audiences at the free questions session, answer my questions sessions and the peer evaluation session. However, it is the positive debate to get a deeper knowledge.

After doing reflection from the finding of the first cycle, I made some improvements. First, I gave support to my students to ask questions and lost their unconfident by letting them ask questions in English as far as they could do. The presenters would type the questions on their new PowerPoint slides and corrected the grammar, spelling and the diction of the questions classically. Second, Presenters must have hard copies for every member of their groups. Third, Every member of the presenters must read their material the night before their presentation day. Fourth, Groups must add their resources of their topic so that they could answer the free questions from the audiences. Fifth, to make point 2, 3 and 4 above worked well, I would tell my students that if the presenter could not answer the audiences 'questions so the unanswered questions would be the homework of the group and must be presented/answered in the following meeting. Sixth, students should have more consultations with the teacher to avoid wrong spelling, grammar and dictions, especially in making a set of questions and answers.

In the second cycle, generally the class condition in teaching and learning process was better than the previous cycle. It could be seen from the results of field notes. There was an increasing number of students who asked questions. Moreover, the presenters prepared their presentation well so that they could answer the audiences' questions very well. Students were more active in learn- 
ing process and enjoyed doing presentations. They were also more enthusiastic to ask and answer questions. They were very proud to use notebooks or laptops in the teaching and learning process, and it also improved their abilities in using ICT. Futhermore, they used to find and share any information related to the lesson from the internet, magazines, books, television or other resources and they also used to consult their difficulties in learning with their friends and the teacher, they did not give up easily when they found unfamiliar words or got difficult questions.

\section{Conclusion}

The implementation of active learning through students' PowerPoint presentations on Report text in the third grade of class 9A of SMP N 1 Bandungan academic year 2014/2015 can create the English active teaching and learning process, especially in their speaking skill. It can be proved from the following fact. First, the improvement could be seen from the students' activities in the group work. There was 100\% improvement in these activities. Second the increase of students' score of being active in consulting their subject with the teacher. Students have no doubtful to consult their difficulties in learning English with the teacher. In the first cycle, the score was $100 \%$ of the class percentages and in the second cycle was also100\%. Third, students were being active in finding resources. It means that they read more books and learned more knowledge. In the first cycle the score of this session was $37.5 \%$ and in the second cycle was $79.2 \%$. Fourth, the result of the field notes also showed that students get positive influences from the implementation of this technique; especially their speaking skill. They are being active in asking and answering questions. They were not afraid anymore in asking and answering questions. In the first cycle, score for students was being active in asking question was 32.5\%, and for the second cycle was $87.5 \%$. Score for students was being active in answering questions in the first cycle was $61.3 \%$ and the second cycle was $90 \%$. I suggest that this technique can also be applied in other subjects. Teachers just need to improve or to add some more ideas that suitable for their students and their subjects. 


\section{REFERENCES}

AlkhasawnehS., F. Abd. Rahman, A. F. bin M. Ayub, S. bin M. Daud. 2012. Developing Multimedia Text for Reading Comprehension Based on Cognitive Theory of Multimedia Teaching, International Journal of Innovative Ideas12(4), 92232-1942.

Bashir, Marriam, et.al. 2001. Factor Effecting Students' English Speaking Skills British Journal of Arts and Social Sciences, BritishJournal Publishing, 2(1), 2046-9578.

Bonwell, C., \&Eison, J. 1991. Active Learning: Creating Excitement in the Classroom. University.http://www.ed.gov/databases/ERIC_ Digests/ed340272.html school. (accessed: August 21 ${ }^{\text {st2014). }}$

Calhoun, E.F. 1994.How to Use Action Research in the Self-Renewing School, Association for Supervision and Curriculum Instructions. Alexandria .Cambridge University Press.

Cameron, B. J. 1999. Active Learning. Green Guide no. 2. Halifax, NS: Society for Teaching and Learning in Higher Education.

Chickering, A. W. \&Gamson, Z. F. 1987. Seven Principles for Good Practice in Undergraduate Education. AAHE Bulletin, 39(7), 3-7.

Chivers-3575-Chapter-01.qxd 5/8/2007 8:38 PM Page 2.

Cross, P. 1987. Teaching for learning. AAHE Bulletin, 39(8), 3-7.

DepartemenPendidikanNasional. 2006. Standar Kompetensi Mata Pelajaran Bahasa Inggris SMP dan MTS, Jakarta: Departemen PendidikanNasional. 
Derewianka, B. 1990. Exploring How Texts Work.Educational Psychology, 444-452.

Eison, J. A., \&Bonwell, C. C. 1993. Recent Works on Using Active Learning Strategies across the Disciplines. Unpublished Manuscript.

Eison, J., 2010. Using Active Learning Instructional Strategies to Create Excitement and Enhance Learning Department of Adult, South Florida: Career \& Higher Education University.

Eison, James. 1988. Enhancing Student Study Skills: How College Faculty Can Help. Cape Girardeau, Southeast Missouri State Univ: Center for Teaching and Learning.

Faust, J. L., \& Paulson, D. R. 1998.Active Learning in the College Classroom. Journal on Excellence in College Teaching, 9 (2), 3-24.

Felder, M. \& Brent, R. 2006. Active learning or How to Get Students Actively Involved in Their Own Learning, Even if You Have 200 of Them in the Class. Available at: http://uwf.edu/cutla/workshops/Active\%20Handout.pdf. (Accessed: August 2014).

Frederick, P. (1987). Student Involvement: Active Learning in Large Classes. San Francisco: Jossey-Bass.

Gerot, L.,\& Peter W., 1994. Making Sense of Functional Grammar. Sydney: Antepodean Educational Enterprise.

Guemide, B. \&Benachaiba, C. 2012.Exploiting ICT and E-Learning in Teacher.

Hardy, J., and Klarwein, Damien. 1990. Written Genres in the Secondary School: Copy Free Text Models for Classroom use. Cairns: Deparment of Education, Queensland.

Jennifer K. K., and William B. W., 2005. Teaching More by Lec- 
turing Less, Colorado:Department of Molecular, Cellular and Developmental Biology University.

Joshua E. \& Susskind. 2004. PowerPoint's power in the Classroom: Enhancing Students' Self-Efficacy and Attitude.

Kemmis, S., \&McTaggart, R. (1988), The Action Research Planner (3rd ed.), Victoria: Deakin University Press.

L.R. Gay, P. Airasian.2003. Education Research, New Jersey :Prentice Hall.

Mayer, R. 2009. The Cambridge Handbook of Multimedia Learning. New York:

Mayer, R. E. and Anderson, R. B. 1992. The Instructive Animation: Helping Students

Mayer, R. E. and Gallini, J. K. 1990. When is an Illustration Worth ten Thousand Words? Journal of Educational Psychology, $82,715-726$.

Meyer, C., \& Jones, T. B. 1993.Promoting Active Learning: Strategies for the College Classroom, San Francisco: Jossey-Bass.

Mills, G.E. 2003. Action Research: A Guide for the Teacher Researcher, 2nd Ed. Upper Saddle River NJ: Prentice Hall.

Mustafa, E.R., 2012. The Effects of Active Learning on Foreign Language Self- Concept and Reading Comprehension Achievement, International Journal for New Trends in Education and Their Implications, 3, 1309-6249.

National Council for Accreditation of Teacher Education (NCATE). 1997. Technology and the New Professional Teacher: Preparing for The 21st Century Classroom. Retrieved November 23, 2009. Avai- 
Improving Active Learning ...

labe: http://www.ncate.org

Paldtrige, B.,1996. Genre, Text Type, and the Language Learning Classroom,ELT Journal Volume, 50/3.

Professional Development in Algeria:the Case of English Secondary School Teachers.

Ryan T. G.,201. The Effect of Multimedia Technology on Learning The Faculty of the Graduate School, Abilene Christian University.

Sagor, R, \& Coz, J. 2004. At Risk Students Reaching and Teaching Them, Larchavant NY: Eye On Education.

Sagor, R. 2000. Guiding School Improvement with Action Research.Alexandria, VA: Association for Supervision and Curriculum Development.

Stuart, J. \& Rutherford, R. J. 1978. Medical Student Concentration During Lectures. The Lancet, 514-516.

Verhoeven, L. and Perfetti, C. 2008. Introduction Advances in Text Comprehension: Model, Process and Development. Applied Cognitive Psychology, 22, 293-301.

Yanguas, I., 2009. Multimedia Glosses and Their Effect on L2 Text Comprehension and Vocabulary Learning, Learning \& Technology, 13(2), 48-67. 